Williams, E.J., and Matthew B. Robinson (2004). Ideology and Criminal Justice: Suggestions for a Pedagogical

Model. Journal of Criminal Justice Education (Fall 2004) 15(2): 373-392. Original version available from Taylor \& Francis (ISSN: 1051-1253)

\title{
IDEOLOGY AND CRIMINAL JUSTICE: SUGGESTIONS FOR A PEDAGOGICAL MODEL
}

\author{
E.J. Williams and Matthew B. Robison
}

\begin{abstract}
Without the explanatory power of general theoretical principles, criminal justice educators are limited to subjectively describing the structure and function of our systems of criminal justice rather than explaining why these systems behave the way they do. Because of this, criminal justice lacks integrity as a legitimate academic discipline that seeks to meet the objectives of a liberal arts education. This paper explores the establishment of ideology as a first principle of criminal justice, derived from political philosophy and sociological theory. We examine ways to build upon this principle as a means of teaching criminal justice within the guise of the liberal arts tradition by guiding students toward a deeper understanding of the nature of our criminal justice systems and their place in larger society.
\end{abstract}


Historically, introductory criminal justice textbooks have contained only cursory reference to the influence of ideological values on the policies and practices of America's criminal justice systems. Recently, however, a trend toward critical analysis of the behavior of police, courts, and corrections has emerged that focuses exclusively on ideology as the analytical tool of choice. For example, Barlow (2000), and Bohm and Haley (2001) include extensive discussion of the influence of ideology on the behavior of America's criminal justice systems. 'Neubauer (2002) includes a chapter-by-chapter in-depth analysis of controversial, ideologically based issues inherent in each stage of the criminal justice process. Clearly, there is an intensifying desire to explain the nature of the behavior of our justice systems. It cannot be purely coincidence that ideology is unanimously and exclusively selected by these (and other scholars to be discussed later) as the analytical tool of choice. This growing interest in the ideological influence on criminal justice policies and practices is not limited to criminal justice scholars.

Not since the backlash against liberal determinism, beginning in the late 1970s, has the media launched so much ideologically centered criticism against our systems of criminal justice. This growing interest in analyzing and explaining the behavior of the systems is an opportunity for scholars to rethink their practical approach to teaching criminal justice. It is time to begin mining the nature of the systems for possible major theoretical principles from which to develop a pedagogical model for teaching criminal justice that meets the goals of a liberal arts education. There appears to be a consensus among those initiating deeper analysis of the systems that ideology is the place to begin.

The philosopher Destutt de Tracy coined the term "ideology" to refer to a "science of ideas" which he hoped would reveal people's unconscious habits of mind. Today, ideology "tends to refer to those very habits of mind -- beliefs, assumptions, expectations, etc.-- which are superimposed on the world in order to give it structure and meaning and which then serve to direct our political or social activities" (Cline 2002: 1). The concept of ideology is commonly 
bifurcated into two polar schools of thought: conservative and liberal. Presently, the dominant ideology underlying the policies and practices of each of our systems of criminal justice in the United States is conservative, characterized by unplanned policies that are tough on crime, individualistic in their focus, and non-rehabilitative (Welsh and Harris 1999). Yet criminal justice scholarship rarely analyzes the effects of this ideology on criminal justice operations. We contend that this omission interferes with our ability to deliver a liberal arts education within criminal justice.

Criminal justice scholars seldom consider the sociopolitical roots of our systems of criminal justice. The criminal justice discipline emanated from the sociology and political science disciplines. Therefore, understanding the nature of the system lies within both of these fields. Because ideological values are the driving force behind the development of political philosophy and sociological theory, this paper explores using ideology as a major theoretical tool for evaluating and explaining the behavior of our systems of criminal justice. We contend that because political ideology is one of the basic foundations of law (Gaus 1999), and since law is the basic foundation of our criminal justice systems, criminal justice operations cannot be understood without examining the central role that ideology plays in shaping the behavior of our systems of justice. We agree with Miller's (1973:143) assertion that "Ideology is the permanent hidden agenda of the criminal justice system."

Within this context, we will briefly review the historical roots of criminal justice as an academic discipline to illustrate the absence of an ideological focus in criminal justice. Next, we explore the meaning of ideology and show how an explicit focus on ideology would be beneficial for criminal justice as one of the liberal arts. Finally, we lay out a new model of criminal justice education that is rooted in ideology. 


\section{CRIMINAL JUSTICE AS AN ACADEMIC DISCIPLINE: \\ FROM VOCATIONAL EDUCATION TO LIBERAL ARTS?}

According to Halsted (1985: 152) criminal justice education in the United States began in 1901, the first year of the National Conference on Criminal Law and Criminology (Stephens 1976). Durham (1992: 36) concurs, writing that "training in crime-related disciplines dates back

to well before the mid-century mark" and that criminal justice degrees were awarded as early as 1930. However, criminal justice did not flourish as a discipline until the 1970s. For example, Halsted (1985: 152) found that by 1965, "only 64 criminal justice programs existed in American colleges and universities. By 1978, however, educational programs in criminal justice manifested a phenomenal growth. Twelve hundred programs had been established by that year" (Simpson 1979).

Halsted attributes the growth of criminal justice to President Johnson's Crime Commission (1965) and the federal government's Law Enforcement Assistance Administration (LEAA), which, starting in the late 1960s, began allocating millions of dollars to colleges and universities in order to increase efficiency in our nation's criminal justice systems (Taylor 1973). Durham (1992) specifically notes the Law Enforcement Educational Program (LEEP), the educational arm of LEAA, which invested more than $\$ 300$ million into education (Weirman and Archambeault 1983).

Because the federal government's interest was primarily to assist law enforcement, it is not surprising that the first stage of criminal justice education in the United States was vocational in nature, what Halsted (1985) calls the "technical/vocational stage." This stage, aimed at providing basic skills, existed from roughly 1965 to 1968 . Its purpose was to provide job skills to officers (the type of training now found in the nation's police academies as well as some community and technical colleges).

Halsted calls the second stage of criminal justice education the "professional/managerial stage," which was in effect from approximately 1968 to 1972 . During these years, criminal 
justice programs were dominated less by training and more by efforts to professionalize criminal justice employees in order to bring about change.

Both LEAA and LEEP were terminated in the early 1980s. This led to declining enrollments for some institutions, while other programs literally folded up their tents. From 1973 to 1976 , the third stage of criminal justice education had already begun to emerge and was in effect at the time Halsted wrote his article. He refers to it as the "empirical/behavioral orientation." It stressed "the importance of considering deviance and crime in the context of existing normative structures" and seemed "to subsume criminal justice under the discipline of sociology or political science" (Halsted 1985: 153-154). As we mentioned in the introduction, criminal justice grew out of these disciplines and has since emerged as a separate academic discipline.

Simpson (1979) suggests that criminal justice programs began to narrow in the 1970 s to a focus on the study of criminality and society's reactions to criminality through systems of criminal justice. Thus, the dominant focus was on "crime causation, observations about trends in criminality, and implications of emerging hypotheses about these for future society" (Halsted, 1985: 155). This may be an apt description of criminology as an academic discipline, but it is not clear if this continues to be the case today for criminal justice as an academic discipline. Most criminal justice research examines the daily operations of police, courts, and corrections. The making of the law, and the complex processes that lead to its creation, are virtually ignored. Robinson (2003) provides an example of this in a review of papers presented at the 2002 meeting of the Academy of Criminal Justice Sciences (ACJS). His analysis shows that the largest category was made up of papers related to types of crime ( $26 \%$ of the total), the second largest category was comprised of papers related to policing (20\%), the third largest category was papers related to corrections (14\%), and the fourth largest category consisted of papers concerning criminal justice education (10\%). No other category comprised as much as $10 \%$ of the total papers scheduled for presentation, including papers on courts (7\%), theories of crime 
(5\%), juvenile justice (4\%), crime prevention (2\%), race (2\%), justice (2\%), methods/statistics (2\%), and a handful of categories, each of which comprised less than $1 \%$ of the total papers (media, comparative criminal justice, crime analysis/crime mapping, ethics, public opinion, and mental health/illness). These "other" categories are ones that receive far more interest by criminologists.

Criminology is widely accepted as a legitimate liberal arts discipline. Jeffrey (1990: xi) defines criminology as a behavioral science characterized by the scientific study of human (and especially criminal and delinquent) behavior. Criminal justice is the study of the agencies of social control that define and react to criminal behavior or "the application of political processes to the criminal." These disciplines have blended together, at least on paper, within many of the nation's most prestigious academic programs. Yet, there still exists a distinction between programs of criminology and criminal justice, marked by their pedagogical approach.

Since its inception as an academic discipline, criminal justice has been in a process of defining and redefining itself and its place in liberal arts education. The criminal justice discipline, according to criminal justice experts such as Todd Clear (2001), continues to be plagued by a lack of respect among other liberal arts disciplines. Clear and others echo Engrall's (1997: 1) complaint that: "Many within the profession of teaching criminal justice lament the disrespect, perceived and real, heaped upon them by their academic and nonacademic brethren." Durham (1992) suggests that for criminal justice education to reach its fullest potential, we must work on overcoming the problem of academic illegitimacy. She suggests doing this by "abandoning the roots of criminal justice education, integrating rigorous academic training with field-based education, and increasing the importance of research" (p. 39). In other words, Durham encourages criminal justice scholars to move away from the vocational aspects of criminal justice training and to engage in more rigorous scholarship. Clear's (2001) recent analysis of the criminal justice discipline shows it has "come of age," so to speak, according to the criteria laid out by Durham only ten years ago. For example, 
Clear shows that today criminal justice has nearly 25 doctoral granting institutions, more than 100 master's granting institutions, and hundreds of bachelor's granting institutions. Clear also observes that criminal justice faculty are at least as productive (and typically more) as scholars from other related disciplines such as sociology, economics, and political science. Clear concludes:

"We are large enough, active enough, scholarly enough, and well enough established to constitute a valid, albeit still new, area of study in our own right. This fact, it seems to me, has momentous significance for our programs, many of which receive little (or grudging) respect in the academy and from the academic administrations of our universities and colleges ... we are no less an area of scholarly potential than any other department in which the institution might invest its resources. The day of the 'cop shop' is long past. According to the data, second-class citizenship is not defensible. We belong, not only as members of the academy, but as leaders in its finest new traditions" (2001: 722).

Clear does acknowledge however, that the criminal justice discipline has significant problems, including having no established language, no developed method, and no accepted theoretical foundation. According to Clear: "Our language and methods are borrowed from other disciplines, and we have no uniform theoretical infrastructure, in part because we employ the various theoretical orientations of those several disciplines. We are an area of study, not a discipline ..." (2001: 711).

Clear notes that, as an academic discipline, criminal justice needs to be "developed and strengthened" (2001: 723). Finally, Clear asserts that criminal justice as an academic discipline "needs to increase its policy-relevant profile." He adds, "criminal justice legislation is routinely enacted without a word from those who study the processes and effects of criminal justice action. This must change" (2001: 723). 
We believe Clear is calling for criminal justice educators to take a stand - on ideological grounds - in order to bring about change in criminal justice practice. Doing so could greatly increase the potential for criminal justice as an academic discipline. Durham's (1992) analysis provides a good rationale for why criminal justice is needed in the realm of the liberal arts. She writes:

"the social scientific approach is invaluable in casting light on issues of inequality, gender, race/ethnicity, class, and social justice, all of which are related to the predicates, components, and processes of the criminal justice system. An understanding of such issues is indispensable to students who are expected to assume leadership roles subsequent to completion of their formal education" (1992: 40).

Durham claims that our value as educators in criminal justice is that we are well equipped, not only to provide basic skills and teach about the "nuts and bolts of justice system operations," but also we can debunk popular myths and provide instruction in ethics (1992: 43). With regard to myth-debunking, Durham explains:

"Probably one of the most fertile areas for myth-debunking is crime and justice. Largely as a result of the attention accorded to crime- and justice-related issues by the print and electronic media, American students generally come to the university fully equipped with a set of perceptions about crime and justice. The perceptions often are at considerable variance with reality, and not surprisingly, the judgments based upon these perceptions are often equally lacking in sensibility" (p. 46).

With regard to ethics, the liberal arts are broadly aimed at building ethical humans and bringing about needed change (Berger and Salem 1984; Edwards 1984). Durham notes:

"Again, criminal justice education is a splendid vehicle for accomplishing objectives that serve the general goals of the liberal arts education. The recurrent dilemma of crime 
and justice offer innumerable case studies and examples that can be used to consider the classic problems in ethics. Issues such as defining good and evil, the nature of human responsibility, and the right of the state to enforce behavioral conformity are not only important in criminal justice, but also are matters of significant general concern" (p. 48).

\section{Problems with criminal justice as an academic discipline}

The primary problem, as we see it, is that most criminal justice education is not aimed at debunking myths of crime and criminal justice and instilling ethics in our students. There are specialized texts on each of these topics, but most introductory criminal justice texts are very thin on these issues. Most criminal justice texts ignore issues crucial to law -- the very foundation of all criminal justice processes -- including power, ideology, politics, lobbying by special interests and political action committees (PACs), manipulation of the law through hard and soft money donations, and so forth. To us, this means criminal justice is not truly a liberal art, for students who are not exposed to such topics will never understand the realities of criminal justice practice.

According to the literature, liberal arts education "has at its center four practices that distinguish it from other kinds of learning: critical thinking, continuing examination of life, encounters with difference, and the free exchange of ideas" (Grinnell 2000). Students engaged in learning in the liberal arts are supposed to learn how to think, how to think for themselves, how to approach the world so that it can be ordered and be understandable, how to be creative, how to see the "big picture" or the whole of the universe, and similar goals (Harris 1991).

Nussbaum (1997) defines an education as liberal to the degree that it liberates the mind "from the bondage of habit and custom, producing people who can function with sensitivity and alertness as citizens of the whole world." According to Nussbaum, the central task of liberal education is to "activate each student's mind, so that choices and actions may emerge from 
independent thought rather than from acceptance of conventional assumptions or dictates" (Grinnell 2000: 1). Thus it is expected that, among liberally educated people, examination of one's self and one's traditions will be a lifelong process. In order to achieve this outcome, liberal arts educators must expose students to perspectives and cultures different from their own. In criminal justice, this would mean teaching students to question the American way of doing justice and reducing crime by, for example, examining other nations' systems of criminal justice and considering possible alternatives to how we do policing, courts, and corrections in the United States.

Sandler (2001: 2) taps a vintage aphorism to explain the value of a liberal arts education: "If all you have is a hammer, everything looks like a nail." He writes:

"That aphorism neatly summarizes the advantage of having a broad knowledge, from which to pull techniques, analogies, etc. for the solution of new problems. One should try to think of more than one solution for a particular problem, then choose the most appropriate solution. People with a narrow expertise will be lucky to find one solution and even luckier if it is a good solution."

Criminal justice students who learn only about the mechanics of police, courts, and corrections will not learn how to think outside the box (or, more accurately, outside the systems), for solutions to problems of crime and justice. And, as we mentioned earlier, students who do not learn about how the law is made and that it is by definition partial, incomplete, and biased in favor of some interests over others, will not understand the present realities of, including problems with, criminal justice practice in the United States.

Even though criminal justice programs in liberal arts institutions have continued to grow, many have not evolved past imparting practical, descriptive information about what our criminal justice systems do and how they do it; thus, they cannot be considered liberal arts programs. If the goal is to progress, it is imperative that criminal justice academics shift their pedagogical 
focus from simply describing our justice systems (or worse, trying subjectively to explain them) to defining the nature of these systems and explaining their behavior based upon objective scientific criteria (i.e., knowledge of principles and causes). Without basic theoretical principles and associated criteria, criminal justice students will be at a loss to develop a general understanding of why our systems of criminal justice behave as they do, and the current pedagogical paradigm will continue to be viewed as an ill-defined, poorly articulated, intellectual outcast among the academic community. More importantly, it will continue to produce graduates who are ill-equipped to problem solve because they do not possess a firm theoretical basis to serve as a guide for understanding and analyzing the nature of the behavior of lawmaking, policing, courts, and corrections.

The search for credibility as a discipline led The Academy of Criminal Justice Sciences (ACJS) to suggest establishing minimum standards for criminal justice education for the purpose of promoting "quality" in criminal justice programs (Southerland 1995:1). The ACJS Ad Hoc Committee on Minimum Standards for Criminal Justice Education includes in its curriculum guidelines the recommendation that "the broad scope of criminology [theories of crime and typologies] and criminal justice be reflected in the curriculum ..." (Southerland 1995:3).

Most criminal justice curricula include a course on criminological theory. Unnithan (1999:101) sees this inclusion as an important exception to the "how-to" quality of most criminal justice courses. He claims that the inclusion of a theory course is our sole defense to charges by Farrell and Koch (1995:51) that our curriculum is:

"anti-intellectual...[and] focuses on the applied rather than on the development of critical skills...that criminal justice instructors are unthinking defenders of the system...[that]...criminal justice represents the death of humanism. ...[and that] the sole purpose of criminal justice education is to train students to fit the mold of the employee...[and] to credential, not to educate." 
We agree that criminological theory is a necessary component of criminal justice education. But we do not agree that its addition to the curriculum is sufficient to achieve the goals of a liberal arts education. We contend that in order for criminal justice to achieve liberal arts goals, it must be taught from first principles deduced from sociopolitical ideology.

\section{THE LOGIC OF USING IDEOLOGY AS THE FIRST PRINCIPLE OF THE STUDY OF CRIMINAL JUSTICE}

Before we move on to the relationship between ideology and criminal justice, consider how criminological theory is also useful for framing the influence of ideology on criminal justice inquiry. Historical analyses of the development of theory point to the conflicts between classicism and positivism as an example. Whereas the classical school of criminological theory represents conservative values expressed with emphasis on punishment, deterrence, retribution, and free will, the positivist school of criminological theory reflects liberal values, indicated by the emphasis on determinism, rehabilitation, prevention, and treatment (Jeffrey 1990:115).

Classicism and positivism are in conflict over the definition of crime, the nature of crime control, and the nature of human nature. Classical thinkers define crime in terms of law, favor punishment to control crime, and place the determinants of human behavior in individual free will and moral responsibility. Positivist thinkers define crime in terms of science, favor treatment and prevention to control crime, and place the determinants of human behavior outside individuals' control. Positivists believe that these determinants are scientifically verifiable (Jeffery 1990: 99). The classical and positivist perspectives help explain the behavior - the policies and practices - of our criminal justice systems. These perspectives are especially relevant to the development of first principles for teaching criminal justice as a liberal art because they did not develop in response to a need to explain crime and criminality. Rather they evolved from established political and social philosophies that sought to understand the 
nature of the changes brought about by the division of labor as societies grew and developed marked in history by the French Revolution (Kinloch 1981:13). Today, they are recognized by sociologists as essential first principles in the development of social philosophy and sociological theory.

Further, Jeffery (1990) reminds us that classicism contains three major philosophical components: social contract theory, hedonistic psychology, and utilitarianism. These components are also useful for framing the behavior of our systems of criminal justice. The social contract theory maintains that some measurable amount of freedom and liberty must be sacrificed in exchange for protection by the state. Hedonistic psychology defines human behavior as selfish, rational, and pleasure seeking (p. 65). Utilitarianism defends sacrificing individual rights for the greater good of society. Each of these has significant relevance for the practice of criminal justice and for understanding how it operates.

According to Jeffery (1990), the utilitarians, Jeremy Bentham, John Locke, John Stuart Mill, Adam Smith, and others, believed that, free from government interference, the selfish individual will behave to maximize pleasure and minimize pain. Locke believed that the individual is naturally good and that too much state control is bad. Locke would place the causes of deviance in the flaws of the state. This philosophy came to be known as liberalism, the ideal of individual freedom from state interference whenever possible.

The conservative philosophy arose from the premise that in the state of nature, the individual is bad. Thomas Hobbes put forth this theory to justify the need for a strong state to control the inherent brutality of human nature. Hobbes believed that the causes of deviance lie within the individual and not in the flaws of the state. Conservatism, as found in Thomas Hobbes and Edmund Burke "places great faith in state control through custom and tradition. The purpose of the state is to guard tradition and to protect the status quo from sudden social changes" (Jeffrey 1990:296). Whereas liberals emphasize the rights of individuals, 
conservatives emphasize "firm discipline and authority by the state to maintain stability and order" (Jeffrey 1990:296).

In further support of our argument is Packer's (1968: 153) assertion that: "The kind of criminal process we have depends importantly on certain value choices that are reflected, implicitly and explicitly, in its habitual functioning." Packer reminds us that his conservative crime control and liberal due process "models" are distortions of reality, and that because they are "normative" models, "there is a danger of seeing one or the other as good or bad" (p. 154). Certainly it goes without saying that, should we as a discipline examine our criminal justice systems based on first principles that stem from ideology, the information should be conveyed in an "objective" manner. By this we mean fair, since the concept of ideology is inherently subjective. If we are to lay claim to being a legitimate arm of the social sciences, we must agree that the goodness or badness of the conservative and liberal ideologies cannot be scientifically verified. We can, however, evaluate the policies promoted by each ideology in terms of their effectiveness at reducing crime and whether or not each achieves or interferes with the achievement of justice (e.g., see Walker 1998). This, as it turns out, is the main purpose of ideology. We have, or should have as criminal justice experts, very deep interests in criminal justice practice; thus our work will be subjective based on our collective ideology, and well it should be. The task here is to define our collective ideology as a discipline of criminal justice. That is, what do we (think we) know about crime and our systems of law-making, police, courts, and corrections? What can we (most of us) agree upon? This would be the logical starting point for defining the ideology of the criminal justice discipline.

\section{Ideology and criminal justice pedagogy}

Criminal justice academicians are rarely trained in liberal arts disciplines such as the humanities (i.e., history, literature, the arts, and so forth). We also rarely teach in these 
departments, and we almost never integrate our work with these disciplines. In describing the types of work that we do and the journals in which we publish, Halsted (1985: 157-158) writes: "[the] perspective notably absent on every level of criminal justice education is the humanistic point of view. There seems little place in today's scholarship for the history of assumptions inherent in today's criminal justice system, much less a pedagogical emphasis on the philosophy of the law and the values inherent in the society and the human condition which supports such a history. One must query why such valueoriented investigations are not encouraged or pursued."

Halsted proposes a new stage of criminal justice education, one related to "fundamental symbols" critical to the understanding of criminal justice - including law, guilt, social order, punishment, personal freedom, violence, justice, and so forth. He writes "inquiry into symbols which are at the heart of the criminal justice system involves questioning the values which are seminal to the meaning of the human condition; this inquiry, of course, has always been one of the goals of the humanities" (p. 160).

Halsted envisions that one way change could be brought about in the real world of criminal justice, when it is needed, is to force the fourth stage of criminal justice education by linking criminal justice with the humanities (also see Miethe 1984; Smith 1987). He suggests “introducing new humanistically oriented courses into the criminal justice curriculum ... [in order to] ... understand all of the central symbols of the criminal justice system through studying it within the context of the humanities" (p. 161).

Halsted offers examples of how these symbols could receive proper attention in certain of the humanities (e.g., learning about punishment through philosophy and religion courses). He suggests offering more courses in areas such as religion, philosophy, history, literature, and the arts, as well as courses in criminal justice that are founded in the humanities. Some of Halsted's examples are "American Criminal Justice Theory," "Theories of Criminal Penalties," "The Criminal and His Guilt," "The History of the Law," "Comparative Criminal Justice Systems," 
"The Philosophy of the Law," "The History of Punishment," "The Meaning of Justice," "Jurisprudence," "Political Economy of Criminal Justice," "Family Violence and Family Law," "The Literature of Justice," "Ethics in Criminal Justice," "Violence in Literature, Music, and Art," "The Influence of Religion on the Administration of Justice," "The Literature of Guilt," and the "Common Law." We wonder how common such courses are in programs of criminal justice across our nation's colleges and universities.

Halsted's argument is for an ideological criminal justice academic discipline and it is consistent with our belief that the criminal justice discipline must be focused squarely on ideology. Earlier, we suggested that ideology is generally understood to mean the beliefs, assumptions, and expectations that are "superimposed on the world in order to give it structure and meaning and which then serve to direct our political or social activities" (Cline, 2002: 1). This is a common understanding of the term.

How has ideology been used in criminal justice thus far? The most notable example comes from Herbert Packer's The Limits of the Criminal Sanction (1968). Packer (1968) developed a systematic way to conceptualize the influence of ideology on criminal justice systems that would take into account the two major, opposing worldviews that infuse themselves into the formulation and implementation of criminal justice policy and practice. Justifying the need for such an analytical tool, Packer described criminal justice as a "paradox," indicated by the gulf between how police, courts, and corrections ought to behave and how they actually behave. He described this gulf as the result of a struggle between two competing goals: efficiency and fairness: "we need ... a model ... that permits us to recognize explicitly the value choices that underlie the details of the criminal process ... [to] ... represent an attempt to abstract the two separate value systems that compete for priority in the operation of the criminal process (p. 153)" [emphasis added].

These models have been widely received by criminal justice educators with a common understanding that the "two separate value systems" described by Packer represent the 
conservative and liberal ideologies (Pollock 1988). Most criminal justice introductory textbooks include brief mention of Packer's crime control and due process models. In most instances, the models are merely described rather than utilized as the important evaluative tools that Packer intended. Moreover, criminal justice scholars have not developed a common vocabulary for conceptualizing the meaning that these models have for understanding the nature, or the essence, of the behavior (practices) of our criminal justice systems. Here are some examples of how these models are treated in the criminal justice literature:

- Schmalleger (1999) characterizes criminal justice as a system that seeks to balance individual rights (due process model) and public order (crime control model) and explains the tension between these two perspectives as the "basis for most policymaking activity in the criminal justice arena" (p. 12). He refers to the actors in each arena as criminal rights activists (liberals) and advocates of law and order (conservatives) (p. 13) [emphasis added].

- Territo, Halsted, and Bromley (1998) describe criminal procedure as a balancing act between conflicting political forces that stress either law and order (the crime control model) or individual rights (the due process model). Both Schmalleger and Territo et al. describe the crime control model the same; however, Schmalleger characterizes the due process model as a "perspective that emphasizes individual rights at all stages of criminal processing" (p. 28), and Territo et al. explain that the due process model emphasizes "the dignity, autonomy, and individual rights of accused persons" (p. 80).

- Cole and Smith (2001) state that balancing the maintenance of public order (the crime control model) with the protection of individual rights (the due process model) amounts to a struggle between conservatives and liberals (p. 6). These authors describe the crime control and due process models but do not conceptually correlate them with the public order/conservative and the individual rights/liberal concepts. 
Packer's models are mentioned simply as "two ways of looking at criminal justice goals and procedures" (p. 6).

- Anderson and Newman (1998) conceptualize Packer's models within the context of Walker's (1994) typology of conservative and liberal theology.

- Adler, Mueller and Laufer (2000) describe the models merely as means for achieving competing goals (pp. 70-71).

- Regoli and Hewitt (1996) substitute the concept "perception" for the concept of ideology, stating, “...criminal justice has become an area of contested terrain. The perceptions and meanings of right and wrong that people bring to the criminal justice system vary greatly, shaping criminal justice policies..." (p. 30). These authors later identify the source of these perceptions as "liberals" and "conservatives" (p. 39).

- Samaha (1997) uniquely frames the "tensions between the values of the crime control and due process models" as an historical phenomenon. "At one extreme is fear of government abuse of power...[and] at the other extreme is the public fear of crime" (pp. 27-28). The former results in "demands for more rules and less discretion" (conservative) and the latter "calls for more discretion to enforce the law" (liberal) (p. 28).

- Smith (1982) simply uses the terms "right" and "left" to identify conservative and liberal values.

- Inciardi (1993) provides evidence of the alternating dominance of the crime control and due process models in an evaluation of the correlation between the ideological composition of the U.S. Supreme Court Justices and their decisions (also see Romero 2000; Sustein 2001). 
The perfunctory mention of these ideology-based models, without using them as tools for critical analysis, calls into question the utility of mentioning them at all. One text that we are aware of (Robinson 2002), utilizes Packer's models of the justice process to evaluate our systems of law, policing, courts, corrections, and the media, and shows conclusively that America's justice systems are entrenched in crime control values. This type of analysis is the exception to the rule of superficial coverage, however.

Most criminal justice scholars, we believe, agree that ideology, and not criminological theory, influences the structures and processes of our criminal justice systems (Bessette 1997; Cowley 1998; Peterson and Palumbo 1997; Schwartz 2001). "Public policy is influenced by ideology, and by stereotypes of crime and criminals as much as, if not more than, by an understanding of the underlying causes of crime and the immediate situations that bring it about" (Barlow 2000: 115). We believe it is naïve to believe that legislators read tests of criminological theories when creating crime control policies.

Alternatively, Unnithan (1999) asserts that the bulk of the structures and processes of our systems of criminal justice is the product of criminological theory. While he acknowledges "the struggle between ideology and theoretically influenced research-based policy" (p. 106), Unnithan believes that we can remedy the inability of most students to integrate criminological explanations with the systemic topics they study in criminal justice by adding a course to the criminal justice curriculum that links theory and policy (p. 104). However, most criminal justice curricula include a course on criminological theory. We do not see evidence that theory is generally utilized as an analytical tool for understanding of the nature of our justice systems.

An example of the potential usefulness of the ideological approach is Barlow and Barlow's (1995) pedagogical model developed to stimulate critical analysis of the behavior of our justice systems toward young black males. These authors recognize "unyielding," ideologically-based assumptions about race and crime held by incoming criminal justice students that are shaped by the news and entertainment media. Barlow and Barlow view this 
as an obstacle to students' understanding of the nature of the behavior of criminal justice in dealing with the issue of race and crime (for examples of how myths of race and crime are created and reinforced, see Robinson 2001). By including an examination of the nature of our justice systems and drawing upon the historical development of its structures and processes, Barlow and Barlow were able to move students past deeply held assumptions and encourage them to reconceptualize the issue of race and crime. These authors were able to empirically demonstrate the importance of developing a liberal arts pedagogical model for teaching criminal justice for the purpose of producing informed, questioning graduates who are willing to take a critical stance on issues, yet, who are open to new ideas and who are able to base their judgments on ideas and evidence (Fowler 2001:4). Barlow and Barlow have shown that ideology can be used effectively in the criminal justice discipline. In other words, it can (and we argue it should) be used as a tool within the criminal justice discipline in order to bring criminal justice more in line with the goals of a liberal arts education.

What is the ideology of the academic discipline of criminal justice? We assert that there is not a clear answer to this question, which is precisely the problem. Because we have not formulated our own collective ideology, we cannot refute that which is put forth by politicians in mainstream media institutions. We are, as Clear (2001) professes, policy-irrelevant.

We assert that the concept of ideology is worth exploring as a legitimate first principle upon which to build a pedagogical model that will bridge the gulf between the liberal arts objective (developing an understanding of why our systems of criminal justice behave the way they do) and our present practical/vocational focus (learning what our systems of criminal justice do and how they do it). The remainder of the paper attempts to flush out this idea in the form of a new pedagogical model. 


\section{A NEW PEDAGOGICAL MODEL ORGANIZED AROUND THE CONCEPT OF IDEOLOGY}

Our goal in the final section of the paper is not to suggest that criminal justice attempt to masquerade as a liberal art. Rather, it is suggested that we use the philosophical and theoretical tools readily available to teach criminal justice in such a way that will meet the goals of a liberal arts education. By using ideology as the framework, we should be able to:

- Encourage critical analysis of the systems of criminal justice, beginning with the law, in terms of their humanity or inhumanity.

- Teach the political nature of the systems, especially of the legislatures and Congress, and guide students toward a deeper understanding of the philosophical underpinnings that determine the systems' structures and processes.

- Assess the implications of "crime" as a social and political construct.

- Explore the various philosophical, social, and political interpretations of the meaning of "justice" and the implications of these ideologically-driven interpretations for the systems' structures and processes.

- Rethink the organization of the criminal justice discipline and the way in which we approach teaching criminal justice courses.

- Rethink the organization of our criminal justice textbooks and critically assess what we omit as much as what we include.

As it now stands, we fear that many of our colleagues teach criminal justice from a practical, descriptive perspective that precludes inculcation of theoretical understanding and critical reasoning that is essential to developing the analytical skills necessary for problemsolving and advancing the field. The process of questioning is an essential goal of a liberal arts education. However the pedagogical model presently used by criminal justice educators is one 
that focuses on doling out answers - a model better suited to technical colleges and training academies. Lacking a pedagogical model that seeks to fulfill liberal arts goals, criminal justice educators are relegating themselves to second-class status and limiting the potential of their graduates to that of maintaining the status quo of criminal justice rather than developing the intellectual skills to evaluate and improve it. We must question the integrity underlying this pedagogical model. We must "expect criminal justice students to achieve more than mere knowledge" (Unnithan 1999:102).

Critical thinking requires that a set of criteria for analyzing any phenomena of interest be clearly defined. "The first principle of organic chemistry," asserted a former undergraduate chemistry professor, "is knowing that carbon is the basic and essential element from which all living matter is constructed." First principles are vital to any scientific endeavor. Once a first principle is fully grasped, it can become evident if and how certain operations emanate from that principle. In turn, given an outcome of an operation, one should be able to state the governing principle. Further, the relation between the operation and the principle should be testable and describable.

So, what is, or what should be, the first principle of criminal justice? We suggest the following deductive statements:

1. Our criminal justice systems are institutions of government social control;

2. As institutions of government social control, our systems of criminal justice are political enterprises.

3. As political enterprises, the key phenomenon that drives criminal justice activity from law making through police, courts, and corrections, is ideology.

4. The manner in which social control of criminal behavior is achieved manifests itself along the lines of a crime control or due process model (Packer 1968), reflecting the general ideologies associated with a bipartisan government structure. 
5. The American bipartisan government structure is represented by conservative and liberal political ideologies.

6. The conservative political ideology is currently the dominant American political ideology, ergo the structure and function (the behavior) of our criminal justice systems are presently under the dominant influence of the conservative crime control model (Walker 1998).

7. Since the conservative crime control model is the dominant influence on our systems of criminal justice, the nature and amount of our criminal justice systems have little to do with actual crime rates and will have more to do with perceptions of crime problems generated in the law and reinforced in the media (Robinson, 2002).

8. Criminal justice processes are therefore not truly aimed at reducing crime or necessarily doing justice, but rather at achieving certain political goals (Reiman, 1998).

As the first principles of criminal justice, these statements can serve as a starting point for a new pedagogical approach to teaching criminal justice. As indicated by the content of the above statements, we believe that the criminal justice discipline should focus less on the how of police, courts, and corrections and more on the why of police, courts, and corrections. This allows criminal justice educators to teach about the important influences of power, politics, and ideology that dominate real-world criminal justice activities. Most importantly, we must add to our curricula an explicit focus on how all criminal justice practice emanates from the law and how this necessarily creates problems with, and limits to, criminal justice practice.

We suggest that ideology and these first principles of criminal justice should provide the basis for all courses in criminal justice. Durham (1992: 49) writes: "Crime and the state response to crime are highly visible processes that involve many fundamental issues regarding the application of values to law formation, the use of coercion to regulate behavior, the definition 
and protection of individual rights, the limits of state power, and the maintenance of social order (emphasis added)." To the degree that this is true, an understanding of ideology is necessary to understand criminal justice operations because ideology forces students to confront, learn about, and use issues such as values, coercion, power, and social order in their coursework.

The practice of police, courts, and corrections is not the inevitable result of responses to crime, as the current approach to teaching criminal justice would have us believe. Rather, as an understanding of ideology allows us to see, the very existence of police, courts, and corrections, as well as their specific actions aimed at only a handful of harmful behaviors, are a function of certain choices of legislators and government bureaucrats. These choices are inherently ideological and therefore cannot be understood without an understanding of ideology and how it operates.

We are calling for a model of teaching that requires such an understanding of ideology to be the underlying principle of all criminal justice courses currently taught within criminal justice programs across the country. Furthermore, we propose courses in the following areas as necessary for bringing about an explicit focus on ideology in criminal justice:

- Criminal justice theory and policy.

- Criminological theory.

- History of law and nature of law-making.

- $\quad$ Theory and philosophy of punishment.

- Ethics.

- Crime and criminal justice mythology.

- Inequality (race, class, gender, etc.).

- Comparative criminal justice systems.

- Symbols and meaning of justice.

- Economics / power and crime and justice. 
- Politics / ideology and crime and justice.

- Crime and justice in literature, music, and art.

Courses such as these are well-suited for defining ideology and illustrating its influence on all of the nation's systems of criminal justice. Each course should give equal consideration to all acts of criminal deviance, including corporations and elites, not just the common street criminal. Our current focus on street crime is unjustifiable given the relative harms caused by white-collar and corporate criminals.

While adding courses to the curricula of criminal justice programs is necessary, it is not sufficient to bring about an explicit ideological focus of criminal justice education. What may be required is a fundamental re-thinking of which courses ought to be taught as part of any core curriculum in a criminal justice program. Typically, core courses include Criminal Law, Police, Courts, and Corrections. By tradition, these courses are taught in an applied nature, and the texts on which the courses are based are written from an applied perspective. Thus, students learn the how of criminal justice, and receive far less information of the why of the criminal law, police, courts, and corrections. The result, we believe, is that criminal justice as an academic discipline is not fulfilling its obligations of a liberal arts education.

\section{CONCLUSION}

Because conservative and liberal ideologies compete for dominance in the United States and in criminal justice practice, we tend to view one as good and the other as bad, depending upon where we sit on the political spectrum. Generalizations based upon political ideology tend to divide groups into the moral and the immoral, the rational and the irrational, the efficient and the inefficient. Some criminal justice scholars pejoratively use the terms "conservative" and "liberal" as expletives in critiques of one another's viewpoints (e.g., see Currie 2000; Kania 1988; Logan and Dilulio 1998; Walker 1998). 
It is time to move past such a simplistic handling of ideology in criminal justice. We believe ideology must be used by criminal justice educators to better prepare criminal justice students to influence meaningful, progressive change. This goal is in keeping with the liberal arts educational objective that seeks to enable people "to function as social critics ... [to] ... analyze social problems ... [and to] ... prescribe necessary changes in society for the common good" (Newton 1989, cited in Farnworth, Longmire and West (1998:40). It is toward this goal that ideology is examined as the most likely candidate to serve as a first principle from which to develop student's understanding of the inherent nature of our systems of criminal justice.

If ideology is the factor determining how much and what kind of justice to mete out to criminal offenders, as we believe it is, and if our systems of criminal justice are at the whim of two competing ideologies that alternately dominate like a swinging pendulum with the passage of time, then human lives are victim to the subjective moral opinions of the dominant ideology. This is a shocking realization when you consider that people's lives are literally at stake. The point is that criminal justice students do not evaluate criminal justice systems from this perspective because they are not taught this perspective. Yet students of sociology and of political science are taught this perspective. They learn to use this knowledge as a tool for understanding and assessing human behavior and the institutions of social control.

Growing evidence suggests that America's systems of criminal justice are in a state of crisis (e.g., see Robinson 2002), yet we almost never hear about this in our textbooks or at conferences, or in our classrooms. Criminal justice educators are not preparing students for the obstacles that will frustrate their efforts to deal with the contradictions and paradoxes that inhere in criminal justice. Equipping students with the cognitive skills to understand the functioning of law-making, policing, courts, and corrections, to "evaluate the effects of actions and social policies and to take responsibility for making the world we live in a better place" (Pitzer 2001:1) is essential for moving criminal justice practice forward as a viable, effective, democratic, and humanitarian enterprise. If the underlying doctrines of political philosophy and sociological 
theory form the basic elements that determine the nature of the behavior of our criminal justice systems, we are doing a disservice to students by omitting this information from our curriculum. It is past time to acknowledge the role of ideology in criminal justice practices so that our students better understand how legislatures, police, courts, and corrections operate and why they behave the way they do. 


\section{REFERENCES}

Adler, F., Mueller, G.O.W. and Laufer, W.S. 2000. Criminal Justice: An Introduction. Boston: McGraw-Hill.

Anderson, P.R. and D.J. Newman. 1998. Introduction to Criminal Justice. Sixth Edition, Boston: McGraw Hill.

Barlow, H. 2000. Criminal Justice in America. Upper Saddle River, NJ: Prentice Hall.

Barlow, M.H. and D. Barlow. 1995. "Confronting Ideologies of Race and Crime in the Classroom." Journal of Criminal Justice Education 6: 105-122.

Berger, R., and R. Salem. 1984. "Criminal Justice and Liberal Arts Education." Wisconsin Sociologist 21(2): 56-69.

Bessette, J.M. 1997. "In Pursuit of Criminal Justice." Public Interest 129: 61-74.

Bohm, R.M. and K.N. Haley. 1999. Introduction to Criminal Justice, Second Edition. Westerville, OH: Glencoe/McGraw-Hill.

Clear, T. (2000). "Has Academic Criminal Justice Come of Age?" Justice Quarterly 18(4): 709-726.

Cline, A. (2002). "Agnosticism/Atheism." [On-line]. www.about.com.

Cole, G.F. and C.E. Smith. 2001. The American System of Criminal Justice. Belmont, CA: Wadsworth.

Cowley, J. 1998. "Changing Public Opinion." Corrections Today 60: 38-40.

Currie, E. 2000. "Confronting Crime: Looking Toward the $21^{\text {st }}$ Century." In B.W. Hancock and P.M. Sharp (eds.), Criminal Justice in America, Second Edition, pp. 407-423. Upper Saddle River, NJ: Prentice Hall.

Durham, A. 1992. "Observations on the Future of Criminal Justice Education: Legitimating the Discipline and Serving the General University Population." Journal of Criminal Justice Education 3(1): 35-52. 
Edwards, R. 1984. "Comments on the Berger-Salem Paper." Wisconsin Sociologist_21(2): 7273.

Engrall, R.P. 1997. "Minimum Standards for Higher Education: A Commentary." ACJS Today 15: 1-24.

Farrell, B. and L. Koch. 1995. "Criminal Justice, Sociology, and Academia." American Sociologist 26: 52-62.

Fowler, B. 2001. "Critical Thinking Across the Curriculum Project." Retrieved July 24, 2001 from the World Wide Web. http://www.kcmetro.cc.mo.us/longview/ctac/ definitions.htm.

Gaus, G. 1999. "A Libertarian Alternative to Liberal Justice." Criminal Justice Ethics 19: 33-43.

Grinnell College. 2000. "Education in the Liberal Arts." [On-line]. www.grinnell.edu/academic/catalog/education/jnl/

Halsted, J. 1985. "Criminal Justice Education and the Humanities: A New Era?" Educational and Psychological Research 5(3): 149-164.

Harris, W. (1991). "Humanities and the Liberal Arts." [On-line]. http://community.middlebury.edu/ -harris/

Inciardi, J.A. 1993. Criminal Justice, Fourth Edition. Ft. Worth, TX: Harcourt Brace Jovanovich.

Jeffrey, C.R. 1990. Criminology. Englewood Cliffs, NJ: Prentice Hall.

Kania, R.E. 1988. "Conservative Ideology in Criminology and Criminal Justice." Justice Quarterly 3: 74-96.

Kinloch, G.C. 1981. Ideology and Contemporary Sociological Theory. Englewood Cliffs, NJ: Prentice Hall.

Logan, C. and J.J. Dilulio, Jr. 1998. "Ten Deadly Myths About Crime and Punishment in U.S." In G.F. Cole and M.G. Gertz (eds.), The Criminal Justice System Seventh 
Edition, pp. 473-490. Belmont, CA: West.

Miethe, T. 1984. "Criminal Justice and Liberal Arts Education: An Extension of and Comment on Berger and Salem." Wisconsin Sociologist 21(2): 77-80.

Miller, W.B. 1973. "Ideology and Criminal Justice Policy: Some Current Issues." Journal Of Criminal Law and Criminology 64: 141-162.

Neubauer, D.W. 2002. America's Courts and the Criminal Justice System, Sixth Edition. Belmont, CA: Wadsworth.

Nussbaum, M. 1997. Cultivating Humanity: A Classical Defense of Reform in Liberal Education. Cambridge, MA: Harvard University Press.

Packer, H. 1968. The Limits of Criminal Sanction. Stanford, CA: Stanford University Press.

Peterson, R. and D.J. Palumbo. 1997. "The Social Construction of Intermediate Punishments." Prison Journal 77: 77.

Pitzer College. 2001. "Educational Objectives." Retrieved from the World Wide Web July 25, 2001. http://www.pitzer.edu/academics/curriculum/objectives.htm.

Pollock, J.M. 1988. Ethics and Criminal Justice. Belmont, CA: West.

Regoli, R.M. and J.D. Hewitt. 1996. Criminal Justice. Englewood Cliffs, NJ: Prentice Hall.

Reiman, J. 1998. The Rich Get Richer and the Poor Get Prison. Boston, MA: Allyn \& Bacon. Robinson, M. 2003. "A Review of ACJS 2002 Papers: What Members Presented About and What They Ignored." ACJS Today, in press. Washington, DC: Academy of Criminal Justice Sciences.

---------- 2002. Justice Blind? Ideals and Realities of American Criminal Justice. Upper Saddle River, NJ: Prentice-Hall. -- 2001. "The Construction and Reinforcement of Myths of Race and Crime." Journal of Contemporary Criminal Justice 24(2): 169-179. 
Romero, F.S. 2000. "The Supreme Court and the Protection of Minority Rights: An Empirical Examination of Racial Discrimination Cases." Law \& Society Review 34: $291-312$.

Samaha, J. 1997. Criminal Justice. Fourth Edition. Minneapolis, MN: West.

Sandler, R. (2001). "Liberal Arts Colleges as Preparation for a Career in Science." [On-line]. www.rbs0.com/college.htm

Schmalleger, F. 1999. Criminal Justice Today, Fifth Edition. Upper Saddle River, NJ: Prentice Hall.

Schwartz, M.D. 2001. "One Critical Criminologist's View of the Future and Value of the ASC." The Criminologist 26: 1-5.

Simpson, A. 1979. Accreditation and its Significance for Programs of Higher Education in Criminology and Criminal Justice Literature: A Review of the Literature. Chicago, IL: University of Illinois.

Smith, B. 1987. "Literature in Criminal Justice Education." Journal of Criminal Justice15: 127-144.

Smith, D. 1982. "Ideology and the Ethos of Economic Crime Control." In E. Elliston and N. Bowie (eds.), Ethics, Public Policy and Criminal Justice. Cambridge, MS: Oelgeschlager, Gunn and Hain.

Southerland, M. 1995. "Should ACJS Adopt Minimum Standards for Criminal Justice Education?" ACJS Today 14: 1,3,7.

Standler, R. 2001. Liberal arts colleges as a preparation for a career in science. [On-line]. Available: http://www.rbs0.com/college.htm

Stephens, G. 1976. "Criminal Justice Education - Past, Present, and Future." Criminal Justice Review 1: 91-120. 
Sustein, C. 2001. "Ideology and Judicial Nominations." FDCH Congressional Testimony June 26, 2001 before the Senate Judiciary Committee. Item No. 32Y200192200008711.

Taylor, K. 1973. "Admission and Retention Policies in Colleges Granting Degrees in Corrections." In V. O'Leary (Ed.), Selected Papers from the Workshop for Correctional Educators in Colleges and Universities. Washington, DC: National Institute on Corrections.

Territo, L., J.B. Halsted and M.L. Bromley. 1998. Crime and Justice in America: A Human Perspective. Boston: Butterworth-Heinemann.

Unnithan, N. P. 1999. "Criminological Theory and Criminal Justice Policy: In Search Of Pedagogical Connections." Journal of Criminal Justice Education 10: 101-110.

Walker, S. 1998. Sense and Nonsense about Crime and Drugs. Belmont, CA: Wadsworth. 1994. Sense and Nonsense about Crime and Drugs. Belmont, CA: Wadsworth.

Walsh, A. and L. Ellis. 1999. "Political Ideology and American Criminologists Explanations for Criminal Behavior." The Criminologist 24: 1, 14.

Weirman, C., and W. Archambeault. 1983. "Assessing the Effects of LEAA Demise on Criminal Justice Higher Education." Journal of Criminal Justice11: 549-561. Welsh, W., and P. Harris. 1999. Criminal Justice Policy \& Planning. Cincinnati, OH: Anderson.

\section{FOOTNOTES}

\footnotetext{
'We refer to the processes of law-making, policing, courts, and corrections as "systems of criminal justice" rather than "the criminal justice system" because of the widely accepted claim that American criminal justice processes do not truly operate as a "system" (see Robinson, 2002).
} 